\title{
Acute and subchronic effects on immune responses of carp (Cyprinus carpio L.) after exposure to deoxynivalenol (DON) in feed
}

\author{
Constanze Pietsch $^{1,2}$ • Barbara A. Katzenback ${ }^{3,6}$ • Erick Garcia-Garcia ${ }^{3,7}$. \\ Carsten Schulz $^{4,5}$ - Miodrag Belosevic ${ }^{3}$ Patricia Burkhardt-Holm ${ }^{2,3}$
}

Received: 11 January 2015 /Revised: 7 May 2015 / Accepted: 10 May 2015 /Published online: 21 May 2015

(C) Society for Mycotoxin Research and Springer-Verlag Berlin Heidelberg 2015

\begin{abstract}
The mycotoxin deoxynivalenol (DON) has been shown to regularly occur at relevant concentrations in feed designed for aquaculture use, but little is known about the consequences of its presence on the organisms that consume the DON-contaminated feed. Previous studies indicated a downregulation of pro-inflammatory responses in carp (Cyprinus carpio L.) after 4 weeks of feeding DON. The present study examined the time course of innate immune responses of carp to orally administered DON. Changes in mRNA levels of immune genes in different organs (head kidney, trunk kidney, spleen, liver, and intestine) were observed indicating immunemodulating properties of DON. The immune-modulatory
\end{abstract}

Electronic supplementary material The online version of this article (doi:10.1007/s12550-015-0226-6) contains supplementary material, which is available to authorized users.

Constanze Pietsch

constanze.pietsch@zhaw.ch

1 Institute of Natural Resource Sciences (IUNR), Zurich University of Applied Sciences (ZHAW), Gruental, P.O. Box,

8820 Waedenswil, Switzerland

2 Man-Society-Environment, Department of Environmental Sciences, University Basel, Vesalgasse 1, 4051 Basel, Switzerland

3 Department of Biological Sciences, University of Alberta, Edmonton, AB T6G 2E9, Canada

4 Gesellschaft für Marine Aquakultur (GMA) mbH, Hafentörn 3, 25761 Büsum, Germany

5 Institute for Animal Breeding and Husbandry, Christian Albrechts-University of Kiel, Olshausestr. 40, 24098 Kiel, Germany

6 Department of Biology, University of Waterloo, 200 University Ave West, Waterloo, N2L 3G1 Ontario, Canada

7 Casa d'Estudis El pont, C/Cervantes 27-bajo, 30150 Villajoyosa, Spain effects during the acute phase of DON exposure were characterized by the activation of both pro- and anti-inflammatory cytokines and enzymes in carp. The subchronic responses to DON were characterized by activation of arginases culminating in increased arginase activity in head kidney leukocytes after 26 days of DON treatment. These results suggest profound effects of this mycotoxin on fish in aquaculture.

Keywords Immunotoxicity $\cdot$ Fish indices $\cdot$ Aquatic toxicology $\cdot$ Mycotoxin $\cdot$ Aquaculture $\cdot$ Cytokines

\section{Introduction}

Different cereals are increasingly used for production of fish feeds in order to satisfy the demand of the steadily growing aquaculture sector (FAO 2012). The occurrence of mycotoxins in fish feeds has been attributed to the contamination of ingredients or finished feeds during storage (Roberts and Patterson 1975; Abdelhamid 1990; Bryden et al. 1980; Ranjan and Sinha 1991; Juszkiewicz and Piskorska-Pliszczynska 1992) as well as fungal development on cereals in the field. Mycotoxin contamination is often due to the presence of fungi of the genus Fusarium (Yazar and Omurtag 2008; Foroud and Eudes 2009), and the most frequently produced mycotoxin by Fusarium strains is the trichothecene deoxynivalenol (DON).

Mycotoxins such as DON in fish feeds have been shown to affect growth, nutrient metabolism, and immune functions in fish (Döll et al. 2011; Hooft et al. 2011; Matejova et al. 2014; Pietsch et al. 2014a, b). Down-regulation of pro-inflammatory immune responses has been observed in carp after feed-borne exposure to three different DON concentrations for 4 weeks, but a clear involvement of anti-inflammatory immune reactions could not be shown (Pietsch et al. 2014a). Thus, further research is necessary to indicate not only possible 
involvement of anti-inflammatory responses at a similar exposure duration but also after shorter and longer exposure to DON in order to unravel regulatory mechanisms of innate immune responses at the molecular and cellular level.

Innate immune responses in fish (as well as in higher vertebrates) are of central importance for host defense and survival (Grayfer et al. 2014). Different types of innate immune mechanisms have been associated with the successful control of various infectious diseases (Iniesta et al. 2005; AlvarezPellitero 2008; Stempin et al. 2010). For example, initiation of an inflammatory response is mediated by key proinflammatory cytokines such as interleukin (IL)- $1 \beta$, tumor necrosis factor alpha (TNF $\alpha)$, and interferon-gamma (IFN $\gamma$ ). Interleukin-8 (IL-8) also exerts pro-inflammatory effects inducing a directional migration of leukocytes to the site of inflammation. Hence, bacterial lipopolysaccharide (LPS), poly I:C, as well as stimulation with TNF $\alpha$ have been shown to increase IL-8 expression in fish cells (Laing et al. 2002; Sangrador-Vegas et al. 2002). Pro-inflammatory cytokines can trigger the production of antimicrobial compounds such as nitric oxide (NO). Production of high amounts of NO are mediated by inducible NO synthases (iNOS) that convert L-arginine to L-citrulline. In cyprinids, iNOS are either constitutively expressed or inducible by endotoxins or pro-inflammatory cytokines (Grayfer et al. 2008, 2010). Early pro-inflammatory reactions are characterized by expression of iNOS by fish phagocytes (Grayfer et al. 2008, 2010).

Inflammation is a tightly regulated process, and one of the regulatory mechanisms involves the synthesis of arginase by the immune cells (Bogdan 2001). Arginases convert arginine to ornithine and urea leading to reduced availability of arginine that is required for the generation of NO (Bansal and Ochoa 2003). In addition, arginases participate in the synthesis of extracellular matrix and tissue repair (Tabor and Tabor 1984; Jenkinson et al. 1996). In fish, two isoforms of arginase have been described that catalyze the same reaction but differ in their tissue distributions and expression levels (Joerink et al. 2006a, b). In addition, anti-inflammatory responses are mediated by cytokines, such as TGF $\beta$ and interleukin-10 (IL-10), which have been identified as regulators of inflammatory responses of fish (Haddad et al. 2008; Grayfer et al. 2011). Since the interaction of pro-inflammatory and anti-inflammatory immune reactions determines the outcome of immune responses, the investigation of both is absolutely essential.

Given that contaminants in fish feed have immunemodulatory effects and that fish are more susceptible to infectious diseases in aquaculture settings, the presence of DON in fish feed may be detrimental to fish health and immunity to disease. In the present study, we examined the acute and subchronic effects of known doses of DON on selected pro- and anti-inflammatory responses of carp (Cyprinus carpio).

\section{Materials and methods}

\section{Chemicals}

All chemicals were obtained from Sigma (Buchs, Switzerland) unless indicated otherwise.

\section{Preparation of feeds}

Preparation of experimental diets without containing any cereals or cereal byproducts has been described in detail previously (Pietsch et al. 2014a). In short, DON (dissolved in ethanol) was added to the ingredients of the experimental diets at a final concentration of $953 \mu \mathrm{g} / \mathrm{kg}$ feed (measured in the diet by high-performance liquid chromatography with diode array detection (HPLC-DAD)) after sample cleanup using immunoaffinity columns (DONprep ${ }^{\mathrm{TM}}$, R-Biopharm, Darmstadt, Germany) as described in Pietsch et al. (2014a)) which has already been shown to affect histological, hematological, and immunological parameters in carp after feeding for 4 weeks (Pietsch et al. 2014a, b). The selected DON concentration is slightly higher than the DON level found in commercial fish feed (Pietsch et al. 2013), whereas control diet was prepared without DON supplementation and did not show traceable amounts of DON in the HPLC-DAD analysis. The mixed ingredients were pelletized, cooled down for $2 \mathrm{~h}$, and then stored at $4{ }^{\circ} \mathrm{C}$ until use. The nutrient and energy content of the DON-contaminated and the basal feed were confirmed using procedures described previously (Pietsch et al. 2014b).

\section{Fish and experimental design}

Carp (9-12 cm in length) were kept in 54-L tanks in a flow through system at the aquatic facilities of the University of Basel (Switzerland). Each feeding group consisted of four tanks each containing four fish. The fish were fed with the experimental diets twice per day at a daily feeding rate of $2.5 \%$ of body weight. For evaluation of immune response development, four time points of exposure were chosen (7, 14,26 , and 56 days) in order to reveal effects of DON administration after short-term and prolonged exposure. At each time point, the experimental groups (control and DON-fed) were evaluated. After the indicated time of exposure, fish were killed, weighed, their length was measured, and blood sampling was conducted as described previously (Pietsch et al. 2014a). The calculation of condition factors was achieved according to equation condition factor $=$ weight $/(\text { length })^{3}$. Tissue from kidneys, spleen, liver, and the proximal part of the intestine was removed and used in subsequent gene expression analyses and functional assays. Spleen weight was recorded to calculate individual spleenosomatic indices as percentage of spleen weight compared to the whole body weight. All animal care protocols had been approved by the Cantonal 
Veterinary Authorities of Basel-Stadt (Switzerland) under the permission number 2410 in accordance with the Swiss animal welfare law.

\section{Preparation of blood smears for differential cell counts}

From each fish, blood was drawn from the caudal vein, immediately after removal from each tank, using heparinized syringes. Blood smears from each fish were prepared in duplicate on glass slides, dried, fixed with $70 \%$ methanol for $2 \mathrm{~min}$, and stained with Wright-Giemsa. This leads to staining of red blood cells in tan-pink, lymphocytes appear reddishpurple, whereas thrombocytes could be identified by their staining pattern in addition to the observation of filopodia as has already been shown for other cyprinid fish (Gregory and Jagadeeswaran 2002). Monocytes and granulocytes were distinguished by their round shape, different size, and different shape of the nucleus. From each slide, 10 pictures were taken randomly at a $\times 400$ magnification (Nikon Eclipse E400 equipped with a Nikon Digital Camera DXM1200F). All cells from each picture were counted so that approximately 3,500 cells were used in total for calculating differential blood cell counts from individual fish.

\section{Gene expression analyses by real-time PCR}

Following harvest, tissues for gene expression analyses were immediately placed in RNAlater ${ }^{\circledR}$ (Fisher Scientific, Reinach, Switzerland) for $24 \mathrm{~h}$ at $4{ }^{\circ} \mathrm{C}$ and thereafter at $-20^{\circ} \mathrm{C}$ until use. RNA was isolated from the tissues using TRIzol ${ }^{\circledR}$ (Invitrogen AG, Basel, Switzerland) according to Bögi et al. (2002) followed by DNase I treatment to remove traces of genomic DNA according to the manufacturer's protocol (DNA-free ${ }^{\mathrm{TM}}$ kit, Ambion ${ }^{\circledR 329}$, distributed by Life Technologies Europe B.V., Zug, Switzerland). Four micrograms of total RNA was reverse transcribed into cDNA using the High-Capacity cDNA Reverse Transcription Kit (Applied Biosystems, distributed by Life Technologies Europe B.V., Zug, Switzerland) according to the manufacturer's directions.

Two micrograms of the resulting cDNA was diluted 1:20 $(v / v)$ in nuclease-free water (Ambion ${ }^{\circledR}$, distributed by Life Technologies Europe B.V., Zug, Switzerland) and used for real-time PCR using Maxima SYBR ${ }^{\circledR}$ Green qPCR Master Mix (2×) (Fermentas Molecular Biology Products, Thermo Fisher Scientific Inc., Wohlen, Switzerland). Primers for carp if $n \gamma$, tumor necrosis factor alpha-2 (tnf $\alpha-2), i l-8, i l-10$, inos, arginase 1 (arg- 1$)$, arginase 2 (arg-2), and beta actin ( $\beta$-actin) were obtained from Integrated DNA Technologies (Toronto, Ontario M5W3P1, Canada), and the corresponding primer sequences can be found in Table 1. All primers were validated for real-time PCR. The Applied Biosystems 7500 Fast RealTime PCR machine and 7500 Fast software (ABI, California, USA) were used for gene expression analyses. The PCR cycling conditions were as follows: an initial denaturation step of $95^{\circ} \mathrm{C}$ for $10 \mathrm{~min}$, followed by 40 cycles of $95{ }^{\circ} \mathrm{C}$ for $15 \mathrm{~s}$ and $60^{\circ} \mathrm{C}$ for $1 \mathrm{~min}$. A melt curve step was added at the end of all qPCR runs to ensure PCR products yielded a single melt peak $\left(95^{\circ} \mathrm{C}\right.$ for $15 \mathrm{~s}, 60^{\circ} \mathrm{C}$ for $1 \mathrm{~min}, 95^{\circ} \mathrm{C}$ for $30 \mathrm{~s}, 60^{\circ} \mathrm{C}$ for $15 \mathrm{~s}$ with $1^{\circ} \mathrm{C}$ increases up to $95^{\circ} \mathrm{C}$ ). All samples were run in triplicate. The results are presented as mean \pm SEM of four fish per experimental group at each time point.

\section{Nitric oxide bioassay}

Primary cell cultures from carp head and trunk kidney tissues were prepared as described by Pietsch et al. (2011). The used method leads to the extraction of approximately $40 \%$ lymphocytes and progenitor cells, $40 \%$ granulocytes, and $20 \%$ macrophages (Pietsch et al. 2008). Approximately $5 \times 10^{6}$ cells per well were allowed to adhere in complete RPMI 1640 medium without phenol red (containing $2.1 \mathrm{~g}$ bicarbonate $\mathrm{L}^{-1}$, $25 \mathrm{mM}$ 4-(2-hydroxyethyl)piperazine-1-ethanesulfonic acid (HEPES), $100 \mathrm{U} \mathrm{ml}^{-1}$ penicillin, $100 \mu \mathrm{g} \mathrm{ml}^{-1}$ streptomycin, $2 \mathrm{mM}$ L-glutamine, and $10 \%$ sterile distilled water) on cell culture plates (Nuclon ${ }^{\mathrm{TM}}$ Delta Surface, distributed by Fisher Scientific, Reinach, Switzerland) overnight by incubation at $25^{\circ} \mathrm{C}$ and $5 \% \mathrm{CO}_{2}$ in the dark. Stimulation of $\mathrm{NO}$ production was done using $30 \mu \mathrm{g} \mathrm{ml}^{-1}$ bacterial lipopolysaccharide (LPS from Escherichia coli, serotype O111:B4)/well. After incubation of cells for further $96 \mathrm{~h}$, NO production was measured using the Griess reaction as described by Pietsch et al. (2008). All experimental incubations were run in three independent replicates.

\section{Cell viability assay}

Cell viability after exposure of fish to control feed or feed containing DON was measured in cells previously used for the NO assay (incubated previously with and without LPS) by assessing the uptake of neutral red (3-amino-7dimethylamino-2-methyl-phenanzine hydrochloride, NR) to evaluate membrane integrity and lysosomal function using the methods described previously (Borenfreund and Puerner 1985). Briefly, a stock solution of NR was prepared with $0.05 \% \mathrm{NR}$ in RPMI medium. Cells were incubated with working solution comprised of $45 \mu \mathrm{l}$ stock solution per ml RPMI medium for $3 \mathrm{~h}$. Afterwards, cells were washed twice with sterile Earle's medium and lysed in $50 \mu$ l ethanol containing $2 \%$ acetic acid. Optical densities from triplicate wells were read at $540 \mathrm{~nm}$ using a plate reader (Infinite M200, Tecan Instruments).

\section{Respiratory burst cell bioassay}

The production of reactive oxygen intermediates (ROI) by immune cells from the head and trunk kidney of control-fed 
Table 1 Primers used in this study

\begin{tabular}{lll}
\hline Primers & Sense sequence $\left(5^{\prime}-3^{\prime}\right)$ & Anti-sense sequence $\left(5^{\prime}-3^{\prime}\right)$ \\
\hline$i f n \gamma$ & CCCATCTGCACCAGCTGAAT & AAGCAGCAGCGACTGACAAG \\
tnf $\alpha-2$ & AGGACCAAGACGTCGTGCAT & GGCTTGTAGCTGCCGTAGGA \\
$i l-8$ & TTATTTTGCTTTCAGGAATGAGTCTTAG & CACACTCTCTATGTGTTTTCAATGC \\
$i l-10$ & GAACGAGATCCTGCGCTTTT & TTGAGTGCAAGTGGTCCTTCTG \\
$i n o s$ & AACAGGTCTGAAAGGGAATCC & CATTATCTCTCATGTCCAGAGTCTCTTCT \\
arg- 1 & TGAGGAGCTTCAGCGGATTAC & CCTATTATTCCCACGCAGTGATG \\
arg-2 & GGAGACCTGGCCTTCAAGCATCT & CTGATTGGCACGTCCAACT \\
$b-$ actin & GCTATGTGGCTCTTGACTTCGA & CCGTCAGGCAGCTCATAGCT \\
\hline
\end{tabular}

and DON-fed fish was assessed with the nitroblue tetrazolium (NBT) assay (Chung and Secombes 1988). Briefly, approximately $5 \times 10^{6}$ leukocytes per well in duplicate were cultured for $96 \mathrm{~h}$ and incubated for $1 \mathrm{~h}$ with $1 \mathrm{mg} \mathrm{NBT} \mathrm{ml}{ }^{-1}$ culture medium with and without $0.24 \mathrm{~g} \mathrm{~m} \mathrm{~m}^{-1}$ phorbol myristate acetate (PMA) as a stimulant for production of reactive oxygen species by leukocytes. Subsequently, the supernatant was discarded, and the cells were fixed using $70 \%$ methanol. Dried plates were incubated with $100 \mu$ l dimethyl sulfoxide (DMSO) and $100 \mu \mathrm{l}$ potassium hydroxide $(\mathrm{KOH})$ to solubilize the formazan. The absorbance at $620 \mathrm{~nm}$ was measured in duplicate wells per treatment with a microplate reader (Infinite M200, Tecan Instruments) using DMSO/KOH alone as blank.

\section{Chemiluminescence assay}

Chemiluminescence was measured after leukocytes from head kidneys and trunk kidneys had been cultured in complete RPMI medium without phenol red at $25{ }^{\circ} \mathrm{C}$ and $5 \% \mathrm{CO}_{2}$ for $24 \mathrm{~h}$ in the dark by using an Infinite M200 (Tecan Group Ltd., Männedorf, Switzerland) in the luminescence mode (Verlhac et al. 1998; Lundén et al. 2002). The cell culture medium was replaced by $50 \mu \mathrm{l}$ Earle's medium per well, followed by the addition of $50 \mu$ l luminol (5-amino-2.3dihydro-1.4-phthalazinedione) solution or $50 \mu \mathrm{l}$ lucigenin (bis- $N$-methylacridinium nitrate) solution at final concentrations of 0.05 and $0.1 \mu \mathrm{mol}$ per well, respectively. Luminol not only allows estimation of myeloperoxidase-dependent activities but also detects reactive oxygen species (ROS), such as hydrogen peroxide, hydroxyl radicals, and singlet oxygen, whereas lucigenin can be used for detection of superoxide anions. Subsequently, the blank luminescence of leukocytes was read. Afterwards, cells were stimulated by addition of $25 \mu$ Earle's medium containing opsonized zymosan at a final concentration of $0.026 \mathrm{mg}$ per well. The latter had been prepared by mixing $100 \mathrm{mg}$ zymosan with $0.85 \%$ sodium chloride solution followed by addition of $4.5 \mathrm{ml}$ freshly prepared carp serum. This mixture was then incubated for $20 \mathrm{~min}$ at $37^{\circ} \mathrm{C}$. Afterwards, the zymosan was washed twice with sodium chloride solution, aliquoted, and stored at $-80^{\circ} \mathrm{C}$ until use.
Luminescence of stimulated leukocytes was recorded for $70 \mathrm{~min}$ at $22{ }^{\circ} \mathrm{C}$ from three independent replicate wells for each experimental incubation, and luminescence values were calculated as relative luminescence units (RLU) per milligram protein. Protein content in all wells was determined using BCA Protein kit (Sigma) according to the manufacturer's protocols.

\section{Arginase assay}

Primary cell cultures from carp kidneys were prepared as described previously (Pietsch et al. 2011). After adherence overnight, approximately $5 \times 10^{6}$ cells per well were further incubated for $24 \mathrm{~h}$ in complete RPMI medium without phenol red in the absence or presence of $1 \mathrm{mM}$ forskolin. After that, arginase activity was measured as described previously (Pietsch et al. 2011). All experimental incubations were run in three independent replicates.

\section{Statistics}

Effects of treatments were determined by comparison of treatment groups $(n=4)$ to controls using the Kruskal-Wallis test followed by the Mann-Whitney $U$ test. The time course of changes of white blood cell population composition was compared using a two-sided ANOVA. A $P$ value of $<0.05$ was accepted as being statistically significant.

\section{Results}

\section{Morphological measurements}

Results from morphological measurements of the fish at the beginning of the experiments (Supplementary (Suppl.) Table 1) and after 7, 14, 26, and 56 days of experimental feeding (Suppl. Table 2) showed that the growth performance of the fish was not influenced by DON treatment compared to the control groups. In addition, the spleenosomatic indices were not found to be different between the treatment groups (Suppl. Table 2). 


\section{Blood cell counts}

Differential blood cell counts (Table 2) revealed that the entire number of white blood cells compared to the number of red blood cells, represented by percent leukocytes, was not significantly different between control-fed and DON-fed groups of fish at 7, 14, 26, or 56 days of experimental feeding. However, within the total leukocyte population, the relative proportion of different leukocyte cell types (lymphocytes, thrombocytes, monocytes, and granulocytes) was affected by experimental DON feeding. Accordingly, thrombocyte numbers were increased to $26.8 \pm 0.9 \%$, and monocyte numbers were decreased to $2.2 \pm 0.5 \%$ in fish receiving DON feed treatment for 7 days compared to the $20.2 \pm 1.2 \%$ thrombocytes and 5.2 $\pm 0.7 \%$ monocytes in control-fed fish (Table 2 ). The relative proportion of lymphocytes and granulocytes was not significantly different between control-fed and DON-fed groups at 7 days of feeding. After 14 days of experimental feeding, the

Table 2 Differential blood cell counts of experimental fish treated with $953 \mu \mathrm{g} / \mathrm{kg}$ feed DON

\begin{tabular}{lll}
\hline & Control & DON \\
\hline Day 7 & & \\
Leukocytes [\% total blood cells] & $3.6 \pm 0.2$ & $3.5 \pm 0.6$ \\
Lymphocytes [\% all white blood cells] & $70.2 \pm 0.7$ & $66.1 \pm 1.9 \mathrm{a}$ \\
Thrombocytes [\% all white blood cells] & $20.2 \pm 1.2$ & $26.8 \pm 0.9^{\mathrm{a}}$ \\
Monocytes [\% all white blood cells] & $5.2 \pm 0.7 \mathrm{a}$ & $2.2 \pm 0.5^{\mathrm{a}}$ \\
Granulocytes [\% all white blood cells] & $4.5 \pm 0.9$ & $4.9 \pm 2.3 \mathrm{a}$ \\
Day 14 & & \\
Leukocytes [\% total blood cells] & $2.7 \pm 0.3$ & $2.4 \pm 0.5$ \\
Lymphocytes [\% all white blood cells] & $66.7 \pm 1.7$ & $47.2 \pm 2.6 \mathrm{~b}$, a \\
Thrombocytes [\% all white blood cells] & $25.9 \pm 2.7$ & $34.4 \pm 2.9$ \\
Monocytes [\% all white blood cells] & $1.8 \pm 0.1 \mathrm{~b}$ & $6.0 \pm 2.3^{\mathrm{a}}$ \\
Granulocytes [\% all white blood cells] & $5.6 \pm 0.9$ & $12.4 \pm 0.9 \mathrm{~b}$, a \\
Day 26 & & \\
Leukocytes [\% total blood cells] & $2.1 \pm 0.3$ & $2.6 \pm 0.5$ \\
Lymphocytes [\% all white blood cells] & $64.3 \pm 3.1$ & $65.3 \pm 2.0 \mathrm{a}, \mathrm{c}$ \\
Thrombocytes [\% all white blood cells] & $23.8 \pm 3.5$ & $22.8 \pm 4.0$ \\
Monocytes [\% all white blood cells] & $5.3 \pm 1.3 \mathrm{a}$ & $6.4 \pm 1.5$ \\
Granulocytes [\% all white blood cells] & $6.7 \pm 0.9$ & $5.6 \pm 1.2 \mathrm{a}, \mathrm{b}$ \\
Day 56 & & \\
Leukocytes [\% total blood cells] & $2.5 \pm 0.5$ & $2.2 \pm 0.4$ \\
Lymphocytes [\% all white blood cells] & $62.6 \pm 2.7$ & $53.4 \pm 4.3 \mathrm{~b}, \mathrm{c}$ \\
Thrombocytes [\% all white blood cells] & $29.4 \pm 4.3$ & $31.8 \pm 5.2$ \\
Monocytes [\% all white blood cells] & $3.1 \pm 0.4 \mathrm{a}, \mathrm{b}$ & $4.7 \pm 1.0$ \\
Granulocytes [\% all white blood cells] & $5.0 \pm 1.3$ & $10.2 \pm 1.9 \mathrm{a}$ \\
\hline
\end{tabular}

$n=4$, mean \pm SEM; different letters indicate significant differences between cell populations over time within the same treatment group; different blood cell populations were counted from 10 randomly taken pictures per slide from each fish

${ }^{a}$ Significant difference to untreated control fish at the same sampling day percentage of lymphocytes was significantly decreased to $47.2 \pm 2.6 \%(66.7 \pm 1.7 \%$ basal feed $)$ and monocytes, and granulocytes were found to be increased to $6.0 \pm 2.3 \%(1.8 \pm$ $0.1 \%$ basal feed) and $12.4 \pm 0.9 \%(5.6 \pm 0.9 \%$ basal feed $)$, respectively, after 14 days of experimental feeding (Table 2). The number of granulocytes in fish treated with DON for 14 days was also significantly higher than in fish treated for only 7 days. In addition, over time, the changes in monocyte numbers of fish sampled at day 14 were also found to be different in the control group compared to control fish at days 7 and 26 which probably influenced the difference to the mean number of monocytes in the DON-treated group due to an unknown reason. A similar difference in monocyte numbers in the DON-treated fish over time was not observed.

Although no difference was observed between differential blood cell counts of DON-treated fish and control fish after 26 and 56 days of experimental feeding, the time course of DON treatment showed a significant difference between the numbers of lymphocytes in DON-treated fish at day 7 and days 14 and 56, respectively, which was not observed in control fish.

\section{Regulation of mRNA transcript levels in tissue from kidneys, spleen, liver, and intestine}

The relative mRNA levels of pro-inflammatory (ifn $\gamma, \operatorname{tnf} \alpha-2$, il-8, inos) and anti-inflammatory (il-10, arg-1, and arg-2) immune-related genes were assessed in head kidney, trunk kidney, spleen, liver, and intestinal tissues from control and DON-fed carp after 7, 14, 26, and 56 days of experimental feeding. Acute exposure of fish to DON feed for 7 days did not result in significant changes of gene expression patterns compared to the control fish in any of the examined tissues (Figs. 1, 2, 3, 4, and 5). After 14 days of exposure, the mRNA expression of $\mathrm{arg}-2$ was increased by 2.3 -fold in head kidney (Fig. 1) and 2.4-fold in trunk kidney (Fig. 2) in DON-treated fish compared to the corresponding tissue in the control-fed fish. The mRNA levels of the other measured proinflammatory (ifn $\gamma$, tnf $\alpha-2, i l-8$, inos) and anti-inflammatory (il-10, arg-1) genes in the head and trunk kidney were not significantly different in DON-fed versus control-fed fish (Figs. 1 and 2). In contrast, after 14 days of experimental feeding, the mRNA levels of all of the measured immune genes were $\sim 2.5-4$-fold higher in the spleen of DON-fed carp compared to control-fed carp (Fig. 3). A similar pattern was present in the liver (Fig. 4) and intestine (Fig. 5) of DON-fed fish, in which a generalized up-regulation of both proinflammatory and anti-inflammatory immune genes was observed compared to control-fed fish. In the liver of DONtreated fish, the mRNA levels of $i l-8$, il-10, arg-1, and arg-2 were increased by 1.9-fold, 2.4-fold, 2.8-fold, and 2.8-fold, respectively (Fig. 4). In the intestine, the mRNA levels of ifn $\gamma$, tnf $\alpha-2$, il-10, inos, arg-1, and arg-2 were significantly 

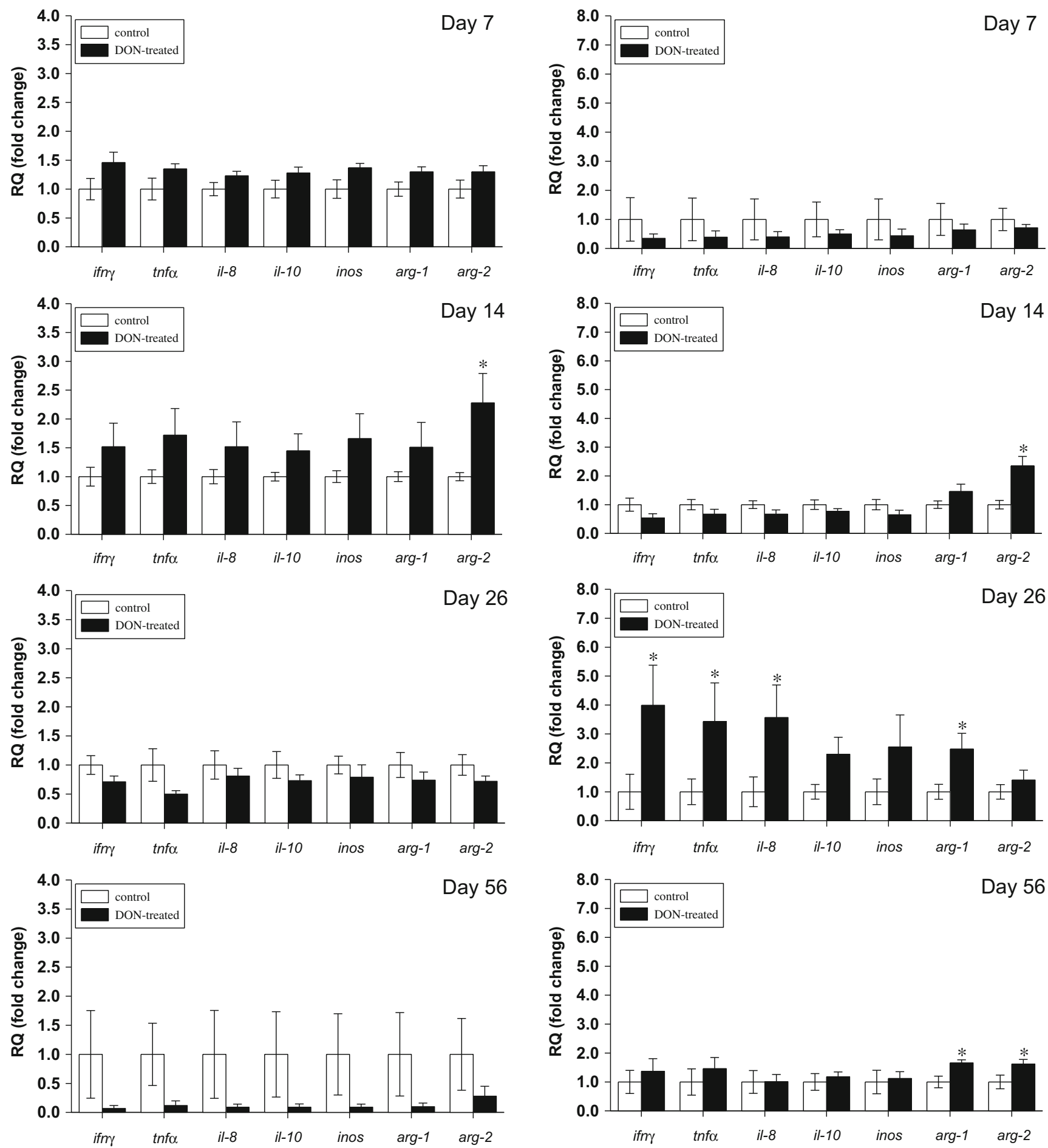

Fig. 1 Relative mRNA expressions in head kidney of fish treated with $953 \mu \mathrm{g} / \mathrm{kg}$ feed DON (black bars) for 7, 14, 26, and 56 days compared to untreated control fish (white bars). All samples were run in triplicate per fish. The mean \pm SEM of four fish is shown. Data were analyzed using the Kruskal-Wallis test followed by the Mann-Whitney $U$ test if groups were significantly different. Asterisks $(*)$ indicate significant difference compared to controls, $P<0.05$

Fig. 2 Relative mRNA expression in trunk kidney of fish treated with $953 \mu \mathrm{g} / \mathrm{kg}$ feed DON (black bars) for 7, 14, 26, and 56 days compared to untreated control fish (white bars). All samples were run in triplicate per fish. The mean \pm SEM of four fish is shown. Data were analyzed using the Kruskal-Wallis test followed by the Mann-Whitney $U$ test if groups were significantly different. Asterisks (*) indicate significant difference compared to controls, $P<0.05$

increased by approximately 3-fold in DON-fed animals compared to that of control animals (Fig. 5).

By 26 days of experimental feeding, mRNA levels of immune genes in DON-fed fish returned to levels comparable to 

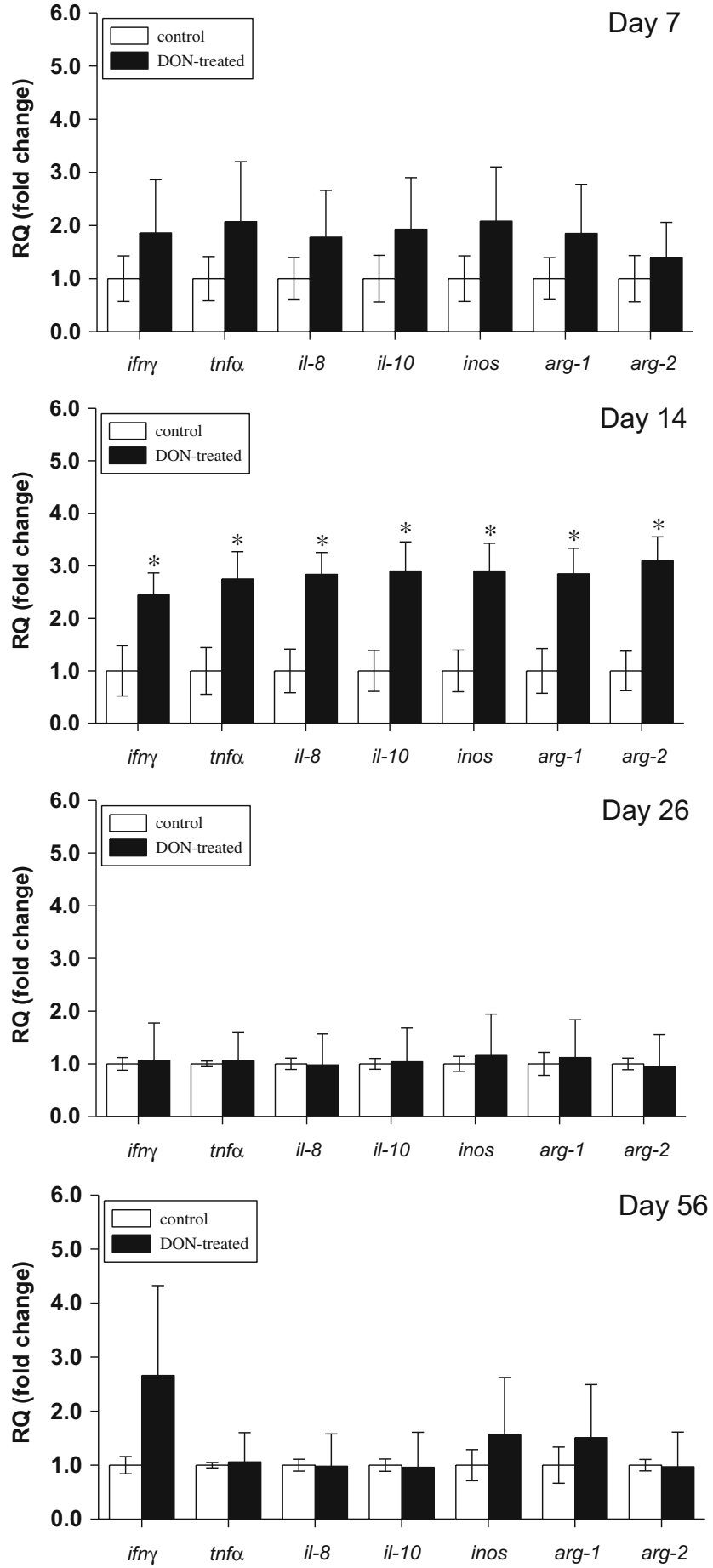

Fig. 3 Relative mRNA expression in spleen of fish treated with $953 \mu \mathrm{g} /$ $\mathrm{kg}$ feed DON (black bars) for 7, 14, 26, and 56 days compared to untreated control fish (white bars). All samples were run in triplicate per fish. The mean \pm SEM of four fish is shown. Data were analyzed using the Kruskal-Wallis test followed by the Mann-Whitney $U$ test if groups were significantly different. Asterisks $(*)$ indicate significant difference compared to controls, $P<0.05$

those observed in the control-fed fish in the head kidney (Fig. 1), spleen (Fig. 3), liver (Fig. 4), and intestinal (Fig. 5) tissues. In contrast, the mRNA levels of ifn $\gamma, \operatorname{tnf} \alpha-2, i l-8$, and
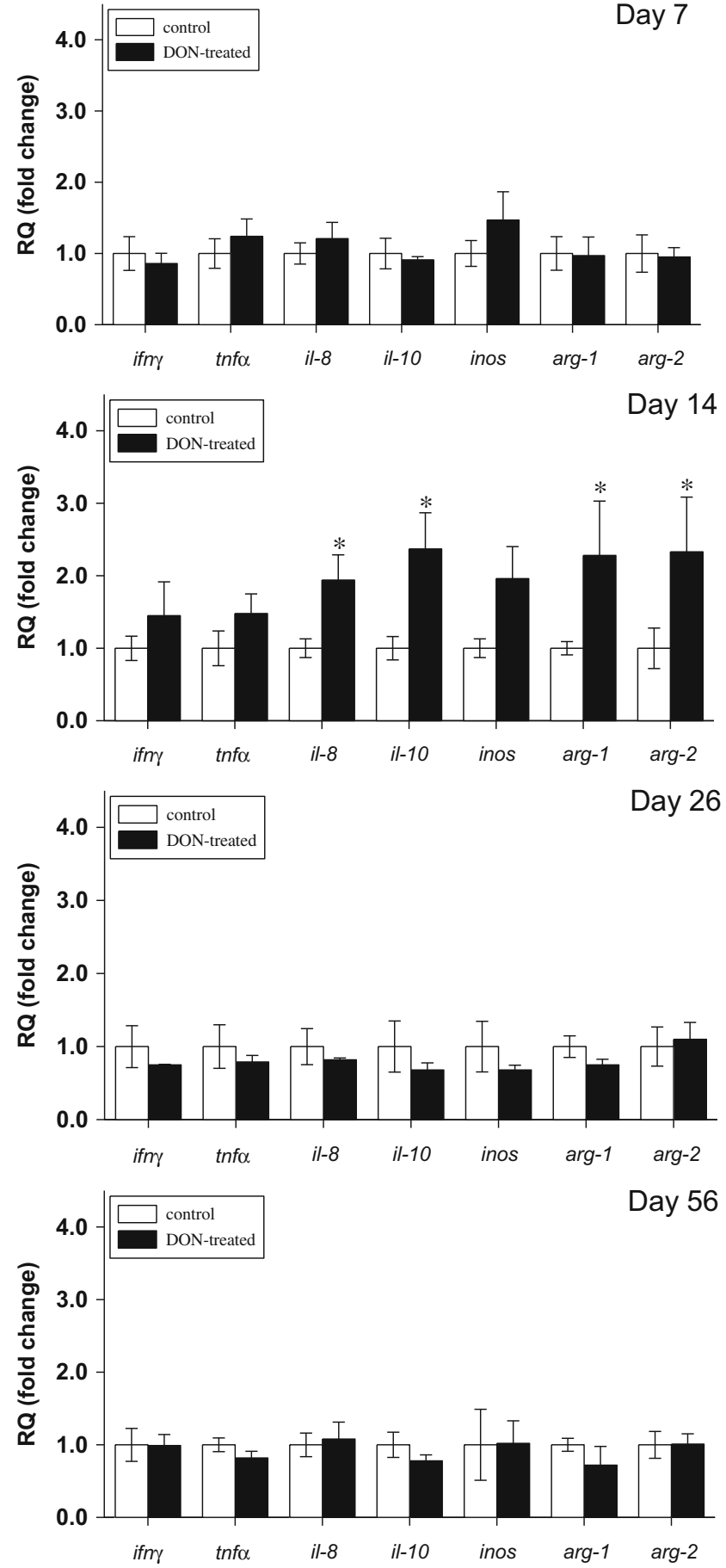

Fig. 4 Relative mRNA expression in liver of fish treated with $953 \mu \mathrm{g} / \mathrm{kg}$ feed DON (black bars) for 7, 14, 26, and 56 days compared to untreated control fish (white bars). All samples were run in triplicate per fish. The mean \pm SEM of four fish is shown. Data were analyzed using the KruskalWallis test followed by the Mann-Whitney $U$ test if groups were significantly different. Asterisks $(*)$ indicate significant difference compared to controls, $P<0.05$

arg-1 were significantly higher in the trunk kidney of DON-fed animals compared to that of the controls (Fig. 2). The mRNA levels of $i l-10$, inos, and $\arg -2$ were not significantly different 

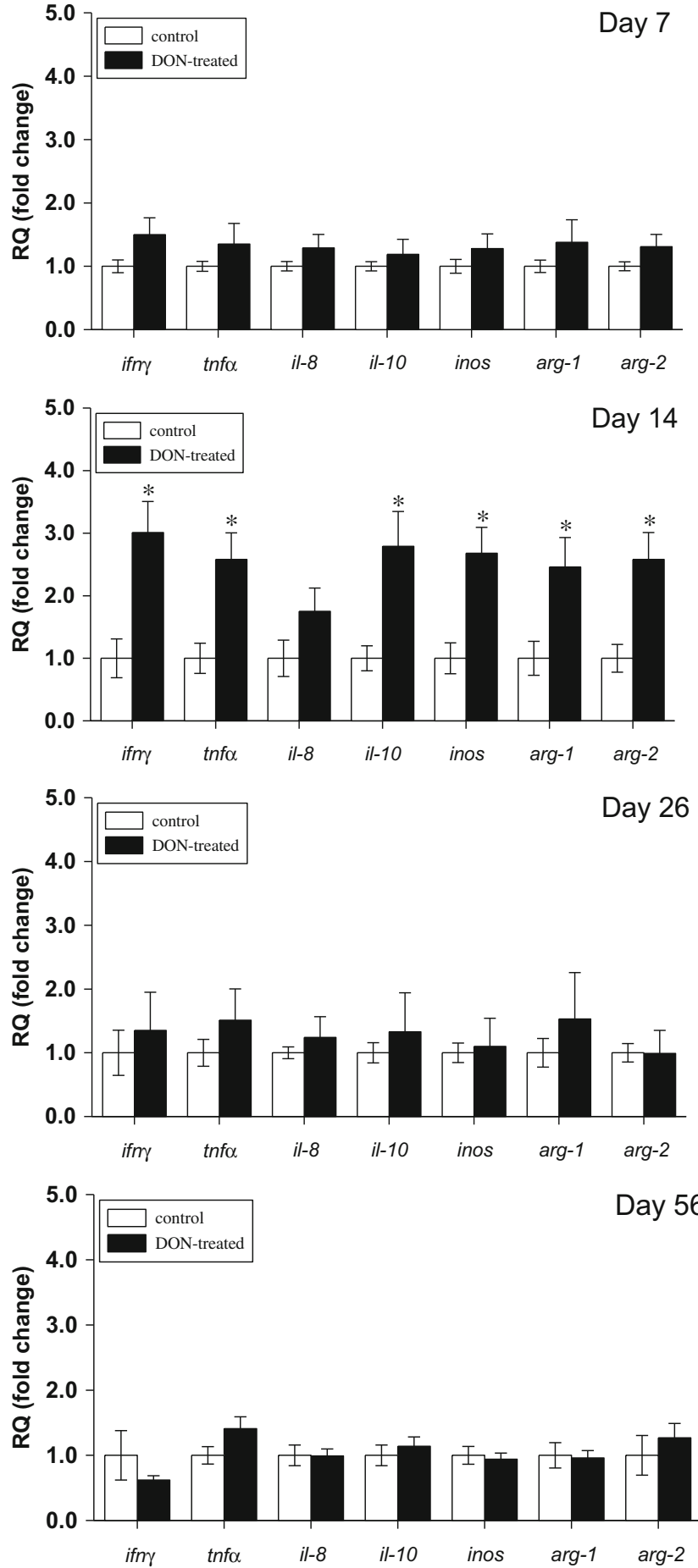

Fig. 5 Relative mRNA expression in intestine of fish treated with $953 \mu \mathrm{g} / \mathrm{kg}$ feed DON (black bars) for 7, 14, 26, and 56 days compared to untreated control fish (white bars). All samples were run in triplicate per fish. The mean \pm SEM of four fish is shown. Data were analyzed using the Kruskal-Wallis test followed by the Mann-Whitney $U$ test if groups were significantly different. Asterisks $\left(^{*}\right)$ indicate significant difference compared to controls, $P<0.05$

in the trunk kidney tissues between DON- and control-fed animals (Fig. 2). Similarly, the mRNA levels of immune genes in the head kidney (Fig. 1), spleen (Fig. 3), liver (Fig. 4), and intestine (Fig. 5) of DON-fed animals were not significantly different from control-fed animals after 56 days of experimental feeding. By 56 days of experimental feeding, the mRNA levels of the majority of immune genes had returned to control levels in the trunk kidney of DON-fed fish, with the exception of arg-1 and arg-2 that were approximately 1.5 -fold higher in the trunk kidney of DON-fed fish (Fig. 2).

\section{Nitric oxide, reactive oxygen species, and arginase activity bioassays}

The production of NO by head kidney and trunk kidney leukocytes from DON-fed and control-fed carp was measured by the Griess reaction. NO production by head kidney leukocytes was not significantly different between controlfed and DON-fed fish (Fig. 6). In contrast, NO production by trunk kidney leukocytes from fish treated with DON for 14 days showed a significant increase compared to the NO production of trunk kidney leukocytes from control fish (Fig. 6). Cell viability after in vitro cultivation of leukocytes for $96 \mathrm{~h}$ with and without LPS did not show any differences for cells derived from head kidney and trunk kidney (Fig. 7), with the exception of trunk kidney cells from fish treated with DON for 56 days which revealed reduced cell viability compared to leukocytes derived from control fish.

Cultured leukocytes from head and trunk kidneys were stimulated with PMA during NBT assays to measure the production of ROS by immune cells. The production of ROS by trunk kidney leukocytes from fish after treatment with DON for 7 days was significantly reduced $(P<0.05)$ compared to that of time-matched control-fed carp (Fig. 8). The production of ROS by head kidney leukocytes was not significantly different between control and DON-fed carp after 7 days of experimental feeding (Fig. 8). No significant differences were observed for ROS production in head kidney or trunk kidney leukocytes after 14, 26, or 56 days of experimental feeding (Fig. 8).

The production of ROS by head kidney and trunk kidney leukocytes was also measured by a chemiluminescence based assay (Suppl. Fig. 1). This assay resulted in significant differences between head kidney cells of fish treated with DON for 26 days compared to the cells of control fish. However, this assay showed higher variability and therefore did not indicate as many differences between DON-treated and control fish as the other assays.

The arginase activity of head kidney and trunk kidney (Fig. 9) leukocytes was measured in DON-fed and controlfed fish after 7, 14, 26, and 56 days of experimental feeding using a plate-based assay. The arginase assays indicated activation of anti-inflammatory pathways in forskolin-stimulated 
Fig. 6 NO production in head kidney and trunk kidney leukocytes of fish treated with $953 \mu \mathrm{g} / \mathrm{kg}$ feed DON for 7,14 , 26 , and 56 days compared to untreated control fish. The nitric oxide production of head kidney cells in the absence (white bars) or presence (black bars) of LPS and in trunk kidney cells in the absence (diagonal bars) or presence (hatched bars) of LPS was measured. All samples were run in triplicate per fish. The data show the mean \pm SEM of four fish. Asterisks $\left({ }^{*}\right)$ indicate significant difference compared to controls, $P<0.05$
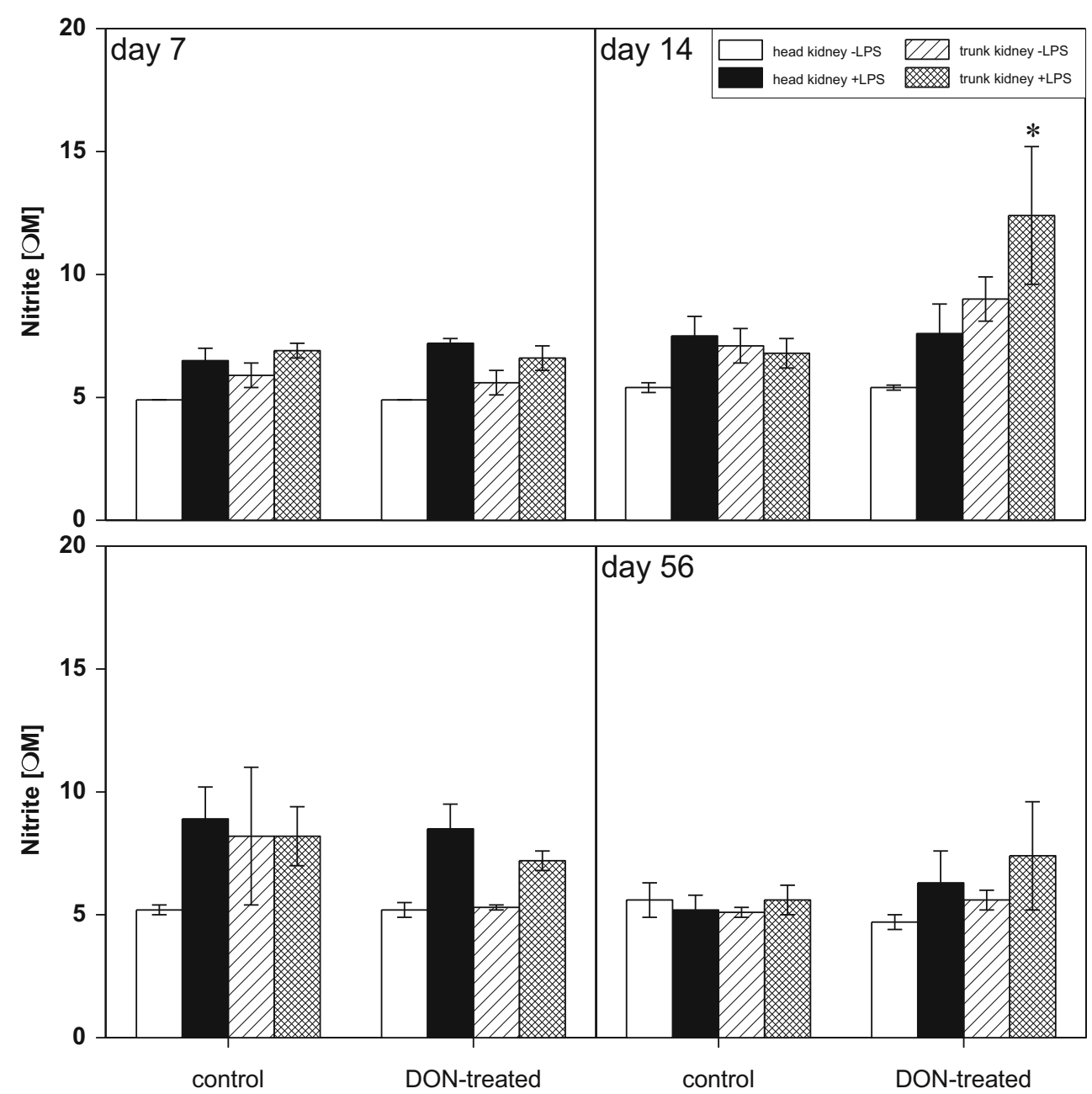

cells from head kidneys derived from fish exposed to DON for 26 days compared to control fish, whereas arginase activity in trunk kidney leukocytes was not found to be different between DON-treated and control fish at all time points examined.

\section{Discussion}

Only a few DON feeding studies using fish have been conducted in the last few years and used concentrations between 352 and 3,000 $\mathrm{mg} \mathrm{kg}^{-1}$ feed (Döll et al. 2011; Hooft et al. 2011; Sanden et al. 2012; Matejova et al. 2014; Pietsch et al. $2014 a, b)$. These concentrations are partly relevant for DON contamination of commercial fish feeds which showed maximum DON levels of up to $825 \mu \mathrm{g} \mathrm{kg}^{-1}$ feed (Pietsch et al. 2013). Most studies investigating the effects of feed-borne mycotoxins on fish use commercial fish feeds and add purified mycotoxins to the exposure group(s) or use mycotoxin-contaminated ingredients for fish feed production. The disadvantage of these experiments is that the control group is commonly exposed to small mycotoxin concentrations and probably also to other feed-borne contaminants due to natural contamination of fish feed ingredients and commercial fish feeds (Santos et al. 2010; Rodrigues and Naehrer 2012; Streit et al. 2012; Barbosa et al. 2013; Pietsch et al. 2013; Tolosa et al. 2013). In contrast, our study prepared experimental diets without cereal ingredients which led to the complete absence of DON in the control group and a concentration of $953 \mu \mathrm{g}$ DON per $\mathrm{kg}$ feed in the exposure group (Pietsch et al. 2014a), whereby other cereal-borne contaminants can mostly be assumed to be absent in these diets.

As far as it is known, DON does not accumulate in fish (Pietsch et al. 2014a), but several metabolic pathways and organ systems can be negatively affected by DON. This includes effects on growth performance in salmonids that were, however, not observed for cyprinid species (Sanden et al. 2012; Pietsch et al. 2014a, b). The latter was also confirmed by the present study. Effects on liver integrity and metabolism have also been shown in carp in a previous study (Pietsch et al. 2014b). These effects are probably at least in part due to the fact that trichothecenes such as DON have been shown to be 
Fig. 7 Neutral red assay after the NO test in head kidney and trunk kidney leukocytes derived from fish treated with $953 \mu \mathrm{g} / \mathrm{kg}$ feed DON for $7,14,26$, and 56 days compared to untreated control fish. The cells from the nitric oxide assay consisted of head kidney cells in the absence (white bars) or presence (black bars) of LPS and in trunk kidney cells in the absence (diagonal bars) or presence (hatched bars) of LPS. All samples were run in triplicate per fish. The data show the mean \pm SEM of four fish. Asterisks $(*)$ indicate significant difference compared to controls, $P<0.05$
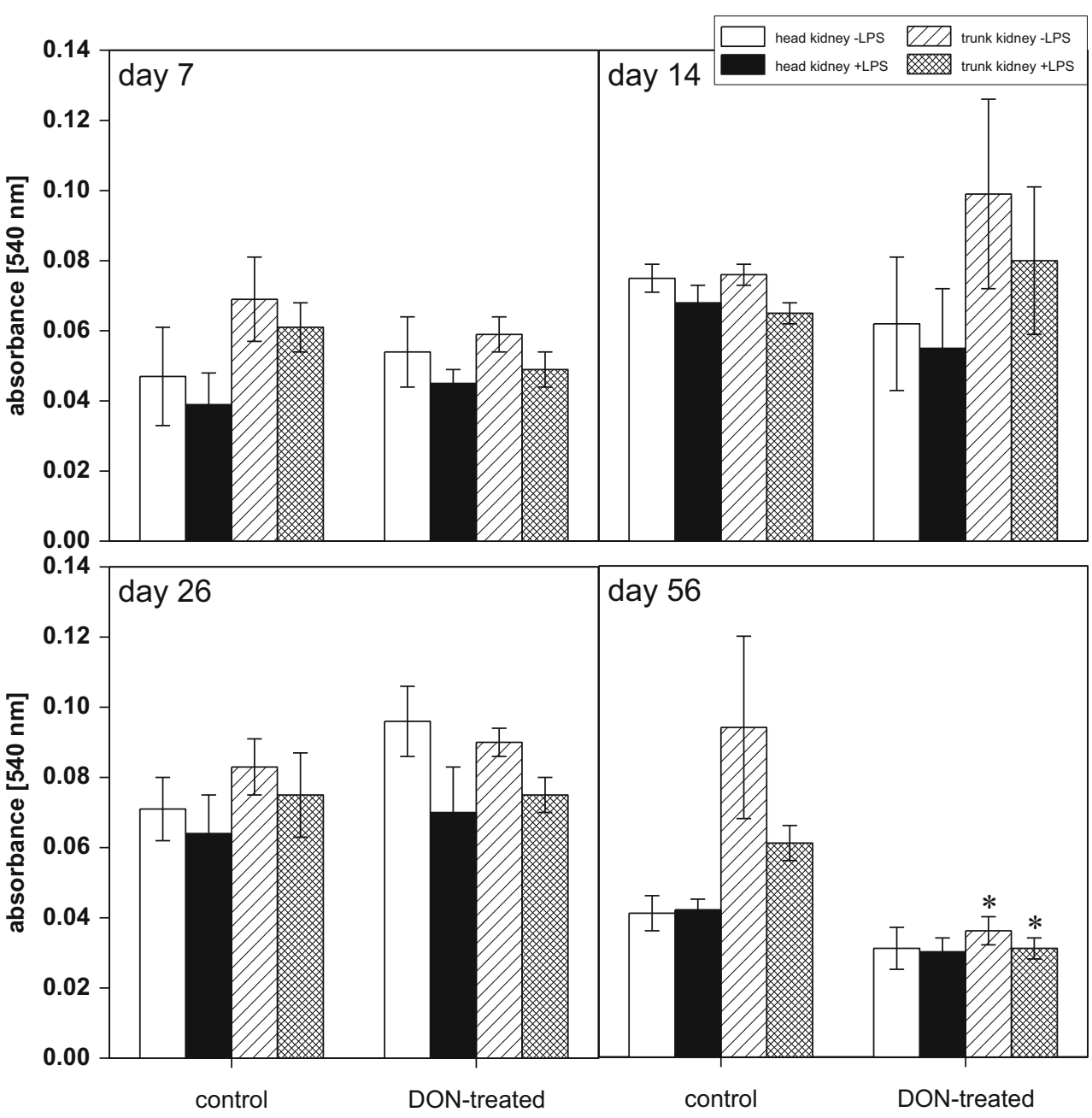

ribotoxic by targeting the $60 \mathrm{~S}$ ribosomal subunit which impairs protein synthesis and transcription, for example, in leukocytes and other actively proliferating eukaryotic cells of higher vertebrates (Shifrin and Anderson 1999). Thus, effects on immune cells have been shown also in fish, but the exact mechanism of action remained obscure (Pietsch et al. 2014a). The effects of DON in mammals have been shown to be both immunosuppressive and immunostimulatory depending on dose and exposure regime (Pestka et al. 2004; Pestka 2008), but a time course of DON exposure has not yet been investigated. Interestingly, the present study revealed effects on immune responses and cell viability in DON-treated fish at days 14, 26, and 56, respectively. Immunosuppressive effects of DON have previously been observed in carp treated for 28 days (Pietsch et al. 2014a). The present study also confirms that the effects of DON are tissue-specific. An acute response was observed that peaks at 14 days in all tissues but disappears thereafter at the mRNA level. The only exception is the trunk kidney. This is probably due to the hematopoietic function of the trunk kidney in cyprinids. Both, head and trunk kidney, exert immunological capacity in cyprinids, but the renal function in the head kidney has been lost. Thus, the physiological role of the trunk kidney as a vital organ for excretion and immune responses in carp is probably more crucial when it comes to immune functions as previously assumed, which was recently also reported for antiviral and antibacterial responses in other cyprinids (Chen et al. 2013).

For DON exposure of fish, differing results can be expected depending on the size of the fish, duration of exposure, and level of exposure. In the present study, the use of small carp revealed acute (at an exposure for 7 and 14 days), but not chronic, effects on white blood cell populations which have not been observed in slightly bigger carp (with an individual weight of 45 to $53 \mathrm{~g}$ ) exposed for 4 weeks in a previous study (Pietsch et al. 2014a), although the cell population percentages in the control fish of both studies were quite similar in both studies. This earlier study used three different DON concentrations in a feeding study with carp for 4 weeks, whereby only the highest concentration of DON $(953 \mu \mathrm{g} / \mathrm{kg}$ feed $)$ showed immunosuppressive effects and no 
Fig. 8 NBT test in head kidney and trunk kidney of fish treated with $953 \mu \mathrm{g} / \mathrm{kg}$ feed DON for 7 , 14,26 , and 56 days, compared to untreated control fish. The production of reactive oxygen intermediates by head kidney (white bars) and trunk kidney (black bars) leukocytes from control (control) and DON-fed (DON-treated) fish was measured using the NBT assay. All samples were run in duplicate per fish. Data are shown as mean \pm SEM of four fish. Asterisks $(*)$ indicate significant difference compared to controls, $P<0.05$

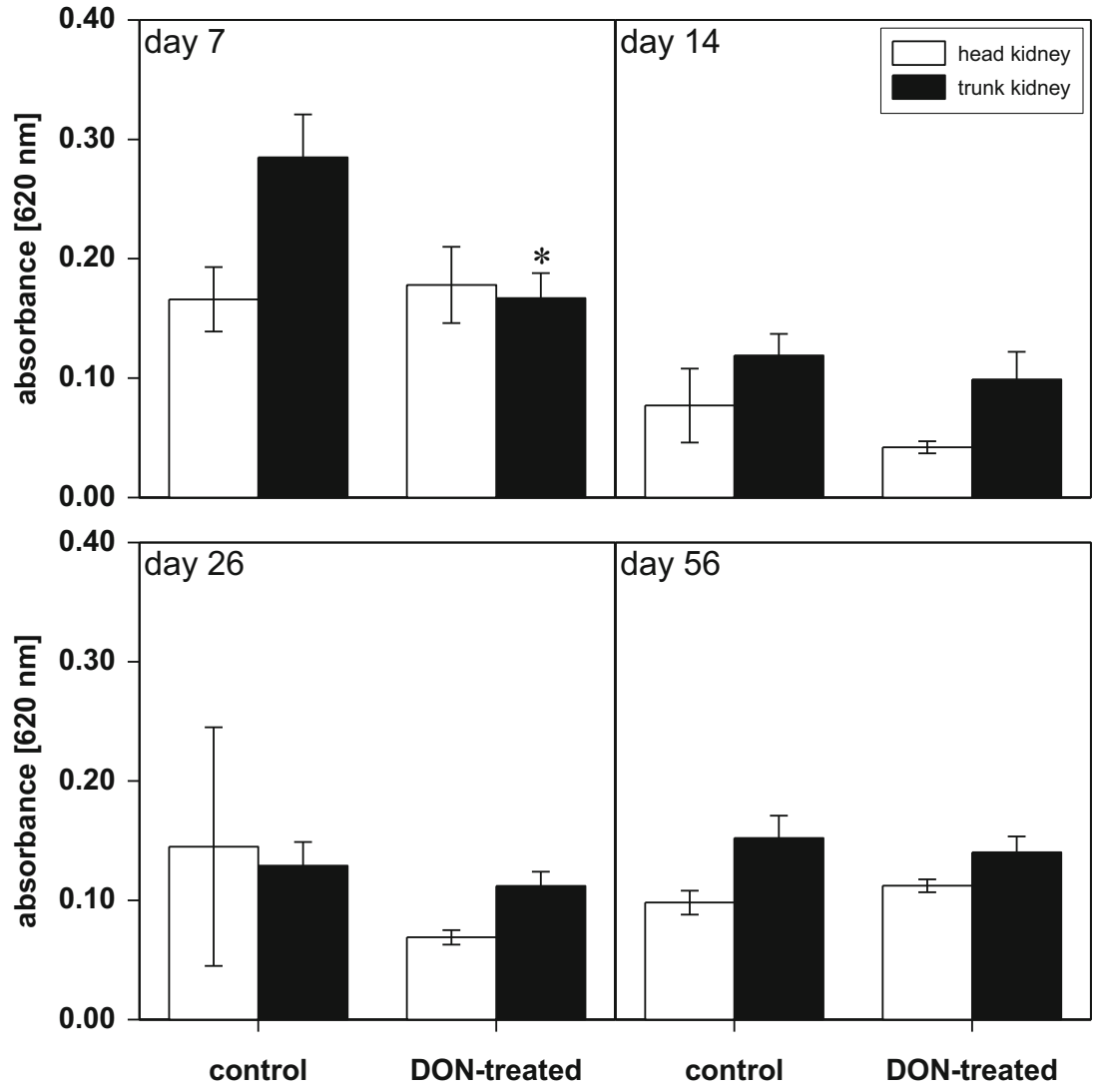

immunostimulating reactions, but reduced pro-inflammatory responses have been observed at the lower DON concentrations (Pietsch et al. 2014a). The lack of immunostimulating effects of DON stays in contrast to mammals where lower DON concentrations have been shown to be immunostimulating (Pestka et al. 2004). The present study indicates some immunostimulatory effects of exposure to $953 \mu \mathrm{g}$ DON per $\mathrm{kg}$ feed for shorter exposure periods (14 and 26 days, as can be seen from the NO production and the chemiluminescence data) that suggests that DON can also have immunostimulating effects in fish, but the exposure duration strongly influences our ability to identify such effects.

Cytokines are known to both up-regulate and downregulate immune functions. The present study showed that pro-inflammatory as well as anti-inflammatory genes are upregulated by DON exposure for 14 days. Since this response was observed in all organs that have been investigated, these results lead to the assumption of a systemic response of carp to DON. There are several mechanisms that may explain how changes in gene expression lead to effects at the protein level including effects of DON on mRNA stability and/or transcription. Such effects of DON on TNF- $\alpha$ have been previously shown in mammals (Sugita-Konishi and Pestka 2001; Chung et al. 2003). Furthermore, trichothecenes including DON, which are known to inhibit protein synthesis, have been reported to stimulate other pro-inflammatory cytokines such as
IL-1 in macrophages (Miller and Atkinson 1986) and IL-2 formation by lymphocytes (Holt et al. 1988) in mammalian systems. Accordingly, DON-induced super-induction of cytokine gene expression has been shown in T helper cells, and especially, the effects of DON on IL-2 were pronounced in vitro as well as in vivo (Azcona-Olivera et al. 1995a, b; Ouyang et al. 1996a, b). Others suggested that this may be related to increased capacity to secrete IL-2, IL-5, and IL-6 (Yan et al. 1997). However, the specific molecular mechanisms for the cytokine super-induction by DON are still incompletely understood. Suppression of immune function by trichothecenes is most readily explained by the capacity of these compounds to bind to ribosomes and inhibit protein synthesis (Bamburg 1983; Rosenstein and LafargeFrayssinet 1983). Nevertheless, further research revealed that, for example, super-induction of IL-2 gene expression by DON is mediated via both transcriptional and/or posttranscriptional mechanisms. Transcriptional mechanisms are known to involve transcription factors such as nuclear factor- $\mathrm{K} B$ and activator protein-1 in murine lymphocytes and EL-4 thymoma cells exposed to DON (Ouyang et al. 1995; Li et al. 2000). In addition, markedly increased IL-2 mRNA stability contributed to the super-induction of IL-2 mRNA expression by DON (Li et al. 1997). Increased transcription of IL-8 after DON exposure involving the transcription factor nuclear factor- $k$ $\mathrm{B}$ has also been observed in human monocytes (Gray 
Fig. 9 Arginase activity in head kidney and trunk kidney cells derived from fish treated with $953 \mu \mathrm{g} / \mathrm{kg}$ feed DON for 7,14 , 26 , and 56 days compared to untreated control fish. The arginase activity of head kidney leukocytes in the absence (white bars) or presence (black bars) of forskolin and the arginase activity of trunk kidney leukocytes in the absence (diagonal bars) or presence (hatched bars) of forskolin was measured and normalized to units of activity per milligram of protein. All samples were run in triplicate per fish. Data are shown as mean \pm SEM of four fish. Asterisks (*) indicate significant difference compared to controls, $P<0.05$
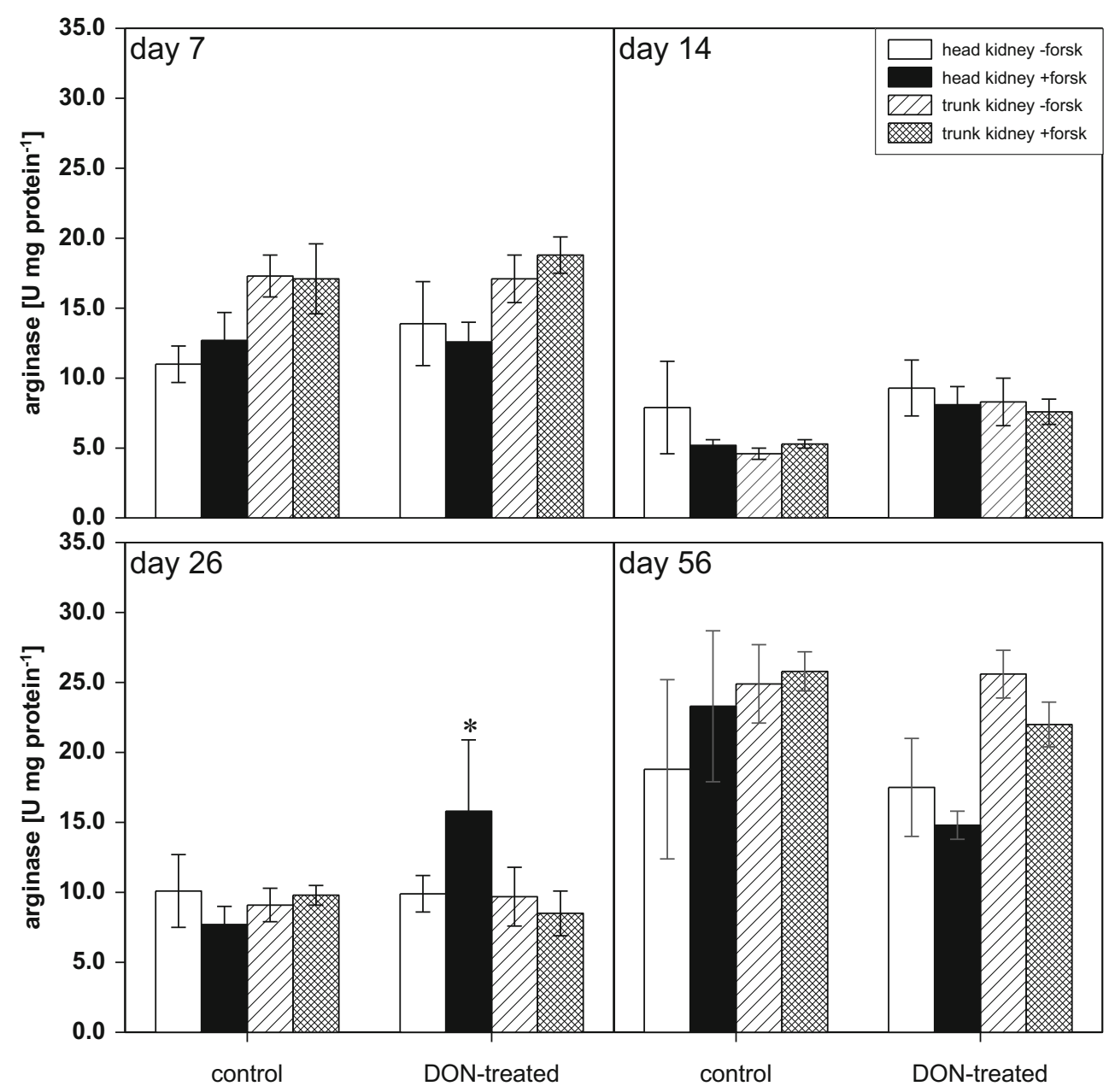

and Pestka 2007), where it was assumed that induction of this cytokine gene is probably due to increases in transcription factors and not due to increased mRNA stability. Nevertheless, a similar super-induction of antiinflammatory genes after acute exposure to DON has not been reported previously.

On day 26 of exposure, mRNA expression levels returned to basal levels in most organs. This was probably due to adaptation to the exposure to pro-inflammatory agents and mechanisms preventing damage from permanent inflammation in tissues, which both can be observed in fish (Perez et al. 2010; Wiegertjes and Forlenza 2010; Hagen et al. 2014). The systemic anti-inflammatory response to DON in carp obviously included increased expression and activity of arginases at different time points which also reveals that regulation of these important immune mediators is taking place at different levels and by different mechanisms.

Other toxic mechanisms of DON, such as impaired membrane function in mammalian systems, have also been suggested to involve mitogen-activated protein (MAP) kinase activation that generates reactive oxygen species (Yang et al. 2000). Mycotoxins of the trichothecene group are thus known to cause lipid peroxidation which can be counteracted by antioxidants (Rizzo et al. 1994). Effects on the level of oxidative stress have already been observed in DON-treated fish and fish cells (Pietsch et al. 2011, 2014a, b). Increased MAP kinase activity could drive activation of transcription factors that promote cytokine production as well as induce apoptosis. Reduced cell viability, immune function, and increased expression of anti-inflammatory genes have been observed after prolonged exposure of carp to DON.

\section{Conclusion}

Besides some immunostimulatory effects of DON during acute exposure, the obtained results confirm the systemic immunosuppressive potential of this mycotoxin in carp which is highly relevant for fish receiving artificial feeds in aquaculture. Since feeds in aquaculture commonly contain more than one mycotoxin at the same time (Barbosa et al. 2013; Pietsch et al. 2013; Tolosa et al. 2013), multitoxin exposure is assumed to be occurring frequently with up to now unknown consequences for the fish. 
Acknowledgments The work of CP was supported by the Basler Stiftung für Experimentelle Zoologie (Basel, Switzerland), the Reisefonds zur Nachwuchsförderung of the University of Basel (Basel, Switzerland), and the Natural Sciences and Engineering Council of Canada (NSERC) by MB. BAK was supported by a NSERC Doctoral Canadian Graduate Scholarship. Furthermore, the authors like to thank Simon Herzog, Michael Schlachter, Florian Nagel, Heidi Schiffer, Irene Kalchhauser, and Joel Gerber for support during the samplings and additional help in the laboratory work. We would also like to thank Sven Dänicke (Friedrich-Loeffler-Institut, Braunschweig, Germany) for the analysis of DON in the experimental feeds.

Conflict of interest The authors declare that there is no conflict of interests regarding the publication of this paper.

\section{References}

Abdelhamid AM (1990) Occurrence of some mycotoxins (aflatoxins, ochratoxin A, citrinin, zearalenone and vomitoxin) in various Egyptian feeds. Arch Tierernahr 40(7):647-664

Alvarez-Pellitero P (2008) Fish immunity and parasite infections: from innate immunity to immunoprophylactic prospects. Vet Immunol Immunopathol 126:171-198

Azcona-Olivera JI, Ouyang Y, Murtha J, Chu FS, Pestka JJ (1995a) Induction of cytokine mRNAs in mice after oral exposure to the trichothecene vomitoxin deoxynivalenol: relationship to toxin distribution and protein synthesis inhibition. Toxicol Appl Pharmacol 133:109-120

Azcona-Olivera JI, Ouyang YL, Warner RL, Linz JE, Pestka JJ (1995b) Effects of vomitoxin deoxynivalenol and cycloheximide on IL-2, 4, 5 and 6 secretion and mRNA levels in murine CD4+ cells. Food Chem Toxicol 35:433-441

Bamburg J (1983) Biological and biochemical actions of trichothecene mycotoxins. In: Hahn F, Kopecko DJ, Müller WEG (eds) Progress in molecular and subcellular biology, vol 8. Springer, Berlin Heidelberg, pp 41-110

Bansal V, Ochoa JB (2003) Arginine availability, arginase, and the immune response. Curr Opin Clin Nutr Metab Care 6:223-228

Barbosa TS, Pereyra CM, Soleiro CA, Dias EO, Oliveira AA, Keller KM, Silva PPO, Cavaglieri LR, Rosa CAR (2013) Mycobiota and mycotoxins present in finished fish feeds from farms in the Rio de Janeiro State. Brazil Int Aquat Res 5:3

Bogdan C (2001) Nitric oxide and the immune response. Nat Immunol 2: 907-916

Bögi C, Levy G, Lutz I, Kloas W (2002) Functional genomics and sexual differentiation in amphibians. Comp Biochem Physiol B 133:559-570

Borenfreund E, Puerner JA (1985) Toxicity determined in vitro by morphological alterations and neutral red absorption. Toxicol Lett 24: $119-124$

Bryden WL, Lloyd AB, Cumming RB (1980) Aflatoxin contamination of Australian animal feeds and suspected cases of mycotoxicosis. Aust Vet J 56(4):176-180

Chen L, Li Q, Su J, Yang C, Li Y, Rao Y (2013) Trunk kidney of grass carp (Ctenopharyngodon idella) mediates immune responses against GCRV and viral/bacterial PAMPs in vivo and in vitro. Fish Shellfish Immunol 34:909-919

Chung S, Secombes CJ (1988) Analysis of events occurring within teleost macrophages during the respiratory burst. Comp Biochem Physiol B 89:39-54

Chung YJ, Zhou HR, Pestka JJ (2003) Transcriptional and posttranscriptional roles for $\mathrm{p} 38$ mitogen-activated protein kinase in upregulation of TNF-alpha expression by deoxyivalenol (vomitoxin). Toxicol Appl Pharmacol 193(2):188-201

Döll S, Valenta H, Baardsen G, Möller P, Koppe W, Stubhaug I, Dänicke S (2011) Effects of increasing concentrations of deoxynivalenol, zearalenone and ochratoxin A in diets for Atlantic salmon (Salmo salar) on performance, health and toxin residues. Proceedings of the 33rd Mycotoxin Workshop. Freising, Germany, 05/31/2011 to 06/ $06 / 2011$, p 25

FAO (2012) The state of world fisheries and aquaculture. Food and Agriculture Organization of the United Nations, Rome

Foroud NA, Eudes F (2009) Trichothecenes in cereal grains. Int J Mol Sci 10:147-173

Gray JS, Pestka JJ (2007) Transcriptional regulation of deoxynivalenol-induced IL-8 expression in human leukocytes. Tox Sci 99(2):502-511

Grayfer L, Walsh JG, Belosevic M (2008) Characterization and functional analysis of goldfish (Carassius auratus L.) tumor necrosis factor alpha. Dev Comp Immunol 32:532-543

Grayfer L, Garcia-Garcia E, Belosevic M (2010) Comparison of macrophage antimicrobial responses induced by type II interferons of the goldfish (Carassius auratus L.). J Biol Chem 285:23537-23547

Grayfer L, Hodgkinson JW, Hitchen SJ, Belosevic M (2011) Characterization and functional analysis of goldfish (Carassius auratus L.) interleukin-10. Mol Immunol 48:563-571

Grayfer L, Hodgkinson JW, Belosevic M (2014) Antimicrobial responses of teleost phagocytes and innate immune evasion strategies of intracellular bacteria. Dev Comp Immunol 43:223-242

Gregory M, Jagadeeswaran P (2002) Selective labeling of zebrafish thrombocytes: quantitation of thrombocyte function and detection during development. Blood Cell Mol Dis 28:418-427

Haddad G, Hanington PC, Wilson EC, Grayfer L, Belosevic M (2008) Molecular and functional characterization of goldfish (Carassius auratus L.) transforming growth factor beta. Dev Comp Immunol 32:654-663

Hagen MO, Katzenback BA, Islam MDS, Gamal El-Din M, Belosevic M (2014) The analysis of goldfish (Carassius auratus L.) innate immune responses after acute and subchronic exposures to oil sands process-affected water. Toxicol Sci 138:59-68

Holt PS, Corrier DE, DeLoach JR (1988) Suppressive and enhancing effect of T-2 toxin on murine lymphocyte activation and interleukin 2 production. Immunopharmacol Immunotoxicol 10:365-385

Hooft JM, Elmor AEHI, Encarnação P, Bureau DP (2011) Rainbow trout (Oncorhynchus mykiss) is extremely sensitive to the feed-borne Fusarium mycotoxin deoxynivalenol (DON). Aquaculture 311: 224-232

Iniesta V, Carcelén J, Molano I, Peixoto PMV, Redondo E, Parra P, Mangas M, Monroy I, Campo ML, Gómez Nieto C, Corraliza I (2005) Arginase I induction during Leishmania major infection mediates the development of disease. Infect Immun 73(9):6085-6090

Jenkinson CP, Grody WW, Cederbaum SD (1996) Comparative properties of arginases. Comp Biochem Physiol B Biochem Mol Biol 114: $107-132$

Joerink M, Forlenza M, Ribeiro CMS, de Vries BJ, Savelkoul HFJ, Wiegertjes GF (2006a) Differential macrophage polarisation during parasitic infections in common carp (Cyprinus carpio L.). Fish Shellfish Immunol 21:561-571

Joerink M, Ribeiro CMS, Stet RJM, Hermsen T, Savelkoul HFJ, Wiegertjes GF (2006b) Head kidney-derived macrophages of common carp (Cyprinus carpio L.) show plasticity and functional polarization upon differential stimulation. J Immunol 177:61-69

Juszkiewicz T, Piskorska-Pliszczynska J (1992) Occurrence of mycotoxins in animal feeds. J Environ Pathol Toxicol Oncol 11(4):211-215

Laing KJ, Zou JJ, Wang T, Bols N, Hirono I, Aoki T, Secombes CJ (2002) Identification and analysis of an interleukin 8-like molecule in 
rainbow trout Oncorhynchus mykiss. Dev Comp Immunol 26(5): 433-444

Li S, Ouyang YL, Dong W, Pestka JJ (1997) Superinduction of IL-2 gene expression by vomitoxin (deoxynivalenol) involves increased mRNA stability. Toxicol Appl Pharmacol 147(2):331-342

Li S, Ouyang Y, Yang GH, Pestka JJ (2000) Modulation of transcription factor AP-1 activity in murine EL-4 thymoma cells by vomitoxin (deoxynivalenol). Toxicol Appl Pharmacol 163(1):17-25

Lundén T, Lilius E, Bylund G (2002) Respiratory burst activity of rainbow trout (Oncorhynchus mykiss) phagocytes is modulated by antimicrobial drugs. Aquaculture 207:203-212

Matejova I, Modra H, Blahova J, Franc A, Fictum P, Sevcikova M, Svobodova Z (2014) The effect of mycotoxin deoxynivalenol on haematological and biochemical indicators and histopathological changes in rainbow trout (Oncorhynchus mykiss). BioMed Res. Int. 2014, Article ID 310680, 5 pages

Miller K, Atkinson HA (1986) The in vitro effects of trichothecenes on the immune system. Food Chem Toxicol 24:545-549

Ouyang YL, Azcona-Olivera JI, Pestka JJ (1995) Effects of trichothecene structure on cytokine secretion and gene expression in murine CD4+ T-cells. Toxicology 104(1-3):187-202

Ouyang YL, Azcona-Olivera JI, Murtha J, Pestka JJ (1996a) Vomitoxinmediated IL-2, IL-4, and IL-5 superinduction in murine CD4+ T cells stimulated with phorbol ester and calcium ionophore: relation to kinetics of proliferation. Toxicol Appl Pharmacol 138:324-334

Ouyang YL, Li S, Pestka JJ (1996b) Effects of vomitoxin deoxynivalenol on transcription factor NF-kappa $\mathrm{B} /$ Rel binding activity in murine EL-4 thymoma and primary CD4+ T cells. Toxicol Appl Pharmacol 140:328-336

Perez T, Balcazar JL, Ruiz-Zarzuela I, Halaihel N, Vendrell D, de Blas I, Muzquiz JL (2010) Host-microbiota interactions within the fish intestinal ecosystem. Mucosal Immunol 3:355-360

Pestka JJ (2008) Mechanisms of deoxynivalenol-induced gene expression and apoptosis. Food Addit Contam Part A Chem Anal Control Expo Risk Assess 25:1128-1140

Pestka JJ, Zhou HR, Moon Y, Chung YJ (2004) Cellular and molecular mechanisms for immune modulation by deoxynivalenol and other trichothecenes: unraveling a paradox. Toxicol Lett 153(1):61-73

Pietsch C, Vogt R, Neumann N, Kloas W (2008) Production of nitric oxide by carp kidney leukocytes is regulated by cyclic adenosine 3',5'monophosphate. Comp Biochem Physiol Part A Physiol 150: $58-65$

Pietsch C, Neumann N, Preuer T, Kloas W (2011) In vivo-treatment with progestogens causes immunosuppression of carp leukocytes (Cyprinus carpio L.) by affecting nitric oxide production and arginase activities. J Fish Biol 79:53-69

Pietsch C, Kersten S, Burkhardt-Holm P, Valenta H, Dänicke S (2013) Occurrence of deoxynivalenol and zearalenone in commercial fish feed - an initial study. Toxins 5:184-192

Pietsch C, Kersten S, Valenta H, Dänicke S, Schulz C, Kloas W, Burkhardt-Holm P (2014a) In vivo effects of deoxynivalenol (DON) on innate immune responses of carp (Cyprinus carpio L.). Food Chem Toxicol 68:44-52

Pietsch C, Schulz C, Robiero P, Kloas W, Burkhardt-Holm P (2014b) Organ damage and altered nutritional condition in carp (Cyprinus carpio L.) after food-borne exposure to the mycotoxin deoxynivalenol (DON). Toxins 6:756-778

Ranjan KS, Sinha AK (1991) Occurrence of mycotoxigenic fungi and mycotoxins in animal feed from Bihar, India. J Sci Food Agricult $56(1): 39-47$
Rizzo A, Atroshi F, Ahotupa M, Sankari S, Elovaara E (1994) Protective effect of antioxidants against free radical-mediated lipid peroxidation induced by DON or T-2 toxin. J Vet Med A 41:81-90

Roberts BA, Patterson DS (1975) Detection of twelve mycotoxins in mixed animal feedstuffs, using a novel membrane cleanup procedure. J Assoc Off Anal Chem 58(6):1178-1181

Rodrigues I, Naehrer K (2012) Prevalence of mycotoxins in feedstuffs and feed surveyed worldwide in 2009 and 2010. Phytopathol Mediterr 51:175-192

Rosenstein Y, Lafarge-Frayssinet C (1983) Inhibitory effect of Fusarium T2-toxin on lymphoid DNA and protein synthesis. Toxicol Appl Pharmacol 70(2):283-288

Sanden M, Jørgensen S, Hemre G-I, Ørnsrud R, Sissener NH (2012) Zebrafish (Danio rerio) as a model for investigating dietary toxic effects of deoxynivalenol contamination in aquaculture feeds. Food Chem Toxicol 50:4441-4448

Sangrador-Vegas A, Lennington JB, Smith TJ (2002) Molecular cloning of an IL-8-like CXC chemokine and tissue factor in rainbow trout (Oncorhynchus mykiss) by use of suppression subtractive hybridization. Cytokine 17(2):66-70

Santos GA, Rodrigues I, Naehrer K, Encarnacao P (2010) Mycotoxins in aquaculture: occurrence in feed components and impact on animal performance. Aquacult Eur 35:6-10

Shifrin VI, Anderson P (1999) Trichothecene mycotoxins trigger a ribotoxic stress response that activates c-Jun N-terminal kinase and p38 mitogen-activated protein kinase and induces apoptosis. J Biol Chem 274:13985-13992

Stempin CC, Dulgerian LR, Garrido VV, Cerban FM (2010) Arginase in parasitic infections: macrophage activation, immunosuppression, and intracellular signals. J. Biomed. Biotechnol. Article ID 683485, 10 pages. doi:10.1155/2010/683485

Streit E, Schatzmayr G, Tassis P, Tzika E, Marin D, Taranu I, Tabuc C, Nicolau A, Aprodu I, Puel O, Oswald IP (2012) Current situation of mycotoxin contamination and co-occurrence in animal feed-focus on Europe. Toxins 4:788-809

Sugita-Konishi Y, Pestka JJ (2001) Differential upregulation of TNFalpha, IL-6, and IL-8 production by deoxynivalenol (vomitoxin) and other 8-ketotrichothecenes in a human macrophage model. J Toxicol Environ Health A 64(8):619-636

Tabor CW, Tabor H (1984) Polyamines. Annu Rev Biochem 53:749-90

Tolosa J, Font G, Manes J, Ferrer E (2013) Natural occurrence of Fusarium mycotoxins in aquaculture fish food. Rev Toxicol 30: 193-197

Verlhac V, Obach A, Gabaudan J, Schüep W, Hole R (1998) Immunomodulation by dietary vitamin $\mathrm{C}$ and glucan in rainbow trout (Oncorhynchus mykiss). Fish Shellfish Immunol 8:409-424

Wiegertjes GF, Forlenza M (2010) Nitrosative stress during infectioninduced inflammation in fish: lessons from a host-parasite infection model. Curr Pharm Des 16:4194-4202

Yan D, Zhou HR, Brooks KH, Pestka JJ (1997) Potential role for IL-5 and IL-6 in enhanced IgA secretion by Peyer's patch cells isolated from mice acutely exposed to vomitoxin. Toxicol 122(1-2):145-158

Yang G, Jarvis BB, Chung Y, Pestka JJ (2000) Apoptosis induction by the satratoxins and other trichothecenes mycotoxins: relationship to ERK, p38 MAPK and SAPK/JNK activation. Toxicol Appl Pharmacol 164:149-160

Yazar S, Omurtag GZ (2008) Fumonisins, trichothecenes and zearalenone in cereals. Int J Mol Sci 9:2062-2090 